\title{
Teachers Understanding about Interesting Online Learning Media
}

\author{
INTAN NURMA YULITA ${ }^{1}$, YENI RIZKA ${ }^{2}$ \\ ${ }^{1}$ Universitas Padjadjaran \\ ${ }^{2}$ MAN 3 Jembrana \\ Email: intan.nurma@unpad.ac.id
}

Received 16 June 2021 | Revised 28 June 2021 | Accepted 29 June 2021

\begin{abstract}
Implementation of Indonesian Education in the New Normal Era after the global Covid-19 pandemic uses an online learning system in accordance with new policies and regulations from the government to break the chain of virus spread in the community. With this system, teachers and students are required to understand online learning media quickly. However, students feel bored with the online learning system because it tends to be monotonous and many tasks are given. In addition, teachers are not necessarily proficient in using these online learning facilities and media, especially to make online learning interesting so that students do not get bored. Therefore, a webinar was conducted to improve teacher's understanding of interesting online learning media such as Kahoot, Mentimeter, and Quizizz. Based on the results of quantitative calculations through the participant's pre and post-tests, the participant's knowledge changes were $28 \%$ on Mentimeter, $23 \%$ on Kahoot, and $18 \%$ on Quizizz.
\end{abstract}

Keywords: online learning, webinar, covid-19 pandemic, kahoot, mentimeter, quizizz

\section{INTRODUCTION}

Education is the most important thing for every country to be able to develop rapidly (Magrath, et al., 2013). A great country will place education as its main priority as a foundation for the creation of a welfare. The Government of the Republic of Indonesia in developing education in Indonesia adheres to one of the goals of the Indonesian nation as stated in the opening of the fourth paragraph of UUD 1945, the intellectual life of the nation. In addition to the objectives stated in the Preamble to the UUD 1945, the body of the constitution includes Article 20, Article 21, Article 28C paragraph (1), Article 31 and Article 32, which also mandates that the government undertakes and organizes a national education system (Saputra, 2018). This new national education system is embodied in UU No. 20 of 2003 concerning the National Education System. The national education system is the entire education component that is interrelated in an integrated manner to achieve national education goals (Asmuni, 2020). 
The emergence of the global COVID-19 pandemic in 2020 has affected people's lives, including the education sector in Indonesia (Churiyah, Sholikhan, Filianti, \& Sakdiyyah, 2020). Since March 2020, the government has issued a Large-Scale Social Restriction (PSBB) policy to deal with the spread of the corona virus (Thorik, 2020). One of the initial PSBB policies was cause all public places to be closed so as not to create crowds that could become a place for the virus to spread (Khasanah, Pramudibyanto, \& Widuroyekti, 2020). After the PSBB policy was implemented, in June 2020 this policy was relaxed and led to a new normal transition period or can also be called the Adaptation of New Habits (IMR) which has been running until now.

Learning activities in schools which were initially carried out directly and face to face turned into Distance Learning (PJJ) or online learning (Purwanto, et al., 2020). Online learning is carried out using various communication media ranging from online meeting media such as zoom meetings, google meets, and social media such as whatsapp, youtube, etc.

The sudden application of online learning creates problems for students. Some students feel bored when participating in the monotonous online learning process because some teachers only give many tasks to students during the learning process (Dewi \& Wajdi, 2021). The difficulties experienced by these students are certainly a real challenge for teachers to create an online learning atmosphere, to be interesting and not boring.

Teachers need to understand the use of interesting online learning media to help students in the learning process (Firman \& Rahayu, 2020). However, the sudden implementation of online learning policies can make it difficult for teachers to understand online learning media that can be used to make the learning process interesting (Pratama, Lestari, \& Astutik, 2020). Therefore, the author conducted a webinar to improve the teacher's understanding of interesting online learning media to use when learning online. This webinar can also help teachers to better understand the various kinds of media that can be used and how to apply them.

The webinar was designed with the theme "Utilizing Digital Technology in the New Normal Era" with the sub-theme "How to Make an Interesting Online Meeting?". Three interesting learning applications used in this webinar are Kahoot, Mentimeter, and Quizizz. Kahoot is a game-based learning platform, which is used as educational technology in schools and other educational institutions, Mentimeter as an easy-to-use presentation software so that the presentations carried out in the learning process are more fun and interactive, and lastly, Quizizz is a web for making games. interactive quizzes that can be used in classroom learning (can be used for learning evaluation).

Research conducted online has advantages such as being able to be carried out effectively and faster because the process is more flexible and can be done from each participant's home. This research can also be a new opportunity from the use of existing technology to see the extent of the results of digital-based research activities. However, the weakness of this research is that it is only conducted online so there are limitations, one of which is the need for a stable internet network.

We held the webinar using the Zoom Meeting platform ang Youtube Live on January 31, 2021, from 09.00 to 12.00 WIB. Total participants oh the webinar were 266 teachers. The purpose of this webinar is to give explanation about Kahoot, Mentimeter, and Quizizz to improve the teacher's understanding of interesting online learning media for the implementation of learning in this new normal era. 


\section{METHOD}

This webinar was hold via Zoom Meeting application and Youtube Live. We had some school partners for this event, namely:

1. SDN 020 Lengkong Besar

2. SDN 2 Gunung Pereng

3. SMPN 16 Tasikmalaya

4. MTS Al Hidayah Jatiserang

5. SMAIT Asy-Syukriyyah

6. SMAN 2 Sumedang

7. SMAN 3 Bukit Tinggi

8. SMKN 1 Majalengka

The participants were not only from our partners, but also general public. Most of participants were university students. Overall, there were 266 participants in this event. Participants knowing about the webinar through advertisements distributed by the research team in online advertising media.

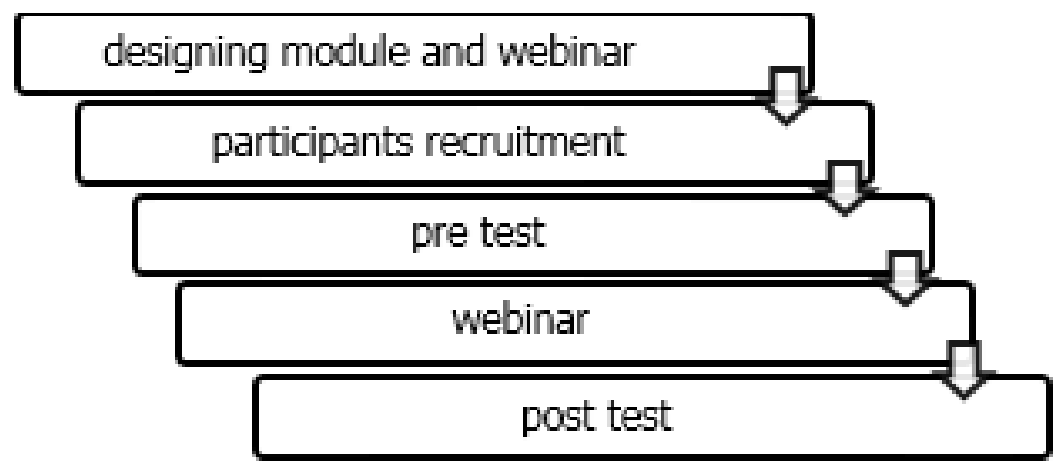

Figure 1. Research methodology

The research methodology is shown in Figure 1. The webinar participants first filled out a pre-test about participant's understanding of online learning media, especially Kahoot, Quizizz, and Mentimeter. We chose these media because of their popularity. Kahoot and Quizizz are two platforms that can support education. This platform is a technology architecture that was developed for the benefit of learning, such as containing features for the interaction of the presenter with the audience, both visually, text, sound and other support. The monotonous learning atmosphere tends to make the delivery of material difficult to absorb, maybe even the audience can ignore it, therefore many presenters think hard to create a unique way to build the spirit of the audience first before starting learning activities. When hearing the word game, the audience will be impressed by hearing it and it becomes a supplement of encouragement for them, then we can combine it with the subject matter that will be delivered. It's true that this will take advantage of technology to create new ways of delivering material and getting a response from the audience. The other hand, Mentimeter is an application that allows users to create presentations and receive real-time feedback on classes, meetings, conferences, and other group activities. Users can get feedback through polls, quizzes, word clouds, Q\&A and other interactive features included in the presentation. So basically, Mentimeter is like a presentation application that can help us interact directly at the same time between teachers and students. Even though we don't actually meet face to face. 
As with other activities, of course there will be feedback from the participants after the activity is carried out as an assessment of the ongoing series and to find out how much impact the participants received and felt regarding the materials presented, especially the material created by the compiler. This assessment is carried out through the process of filling out the pre-test and post-test forms which in this case are included as the compiler's task during the D-Day of the event to share the link to the participants.

This assessment consists of several questions that will be filled out by the participants and made into a scale of 1 to 5 where the number 1 refers to the statement "Highly Do Not Understand" and the number 5 refers to the statement "Already Understand". This pre-test aims to measure the initial understanding of participants. Some questions of pre-test are shown in Figure 2.
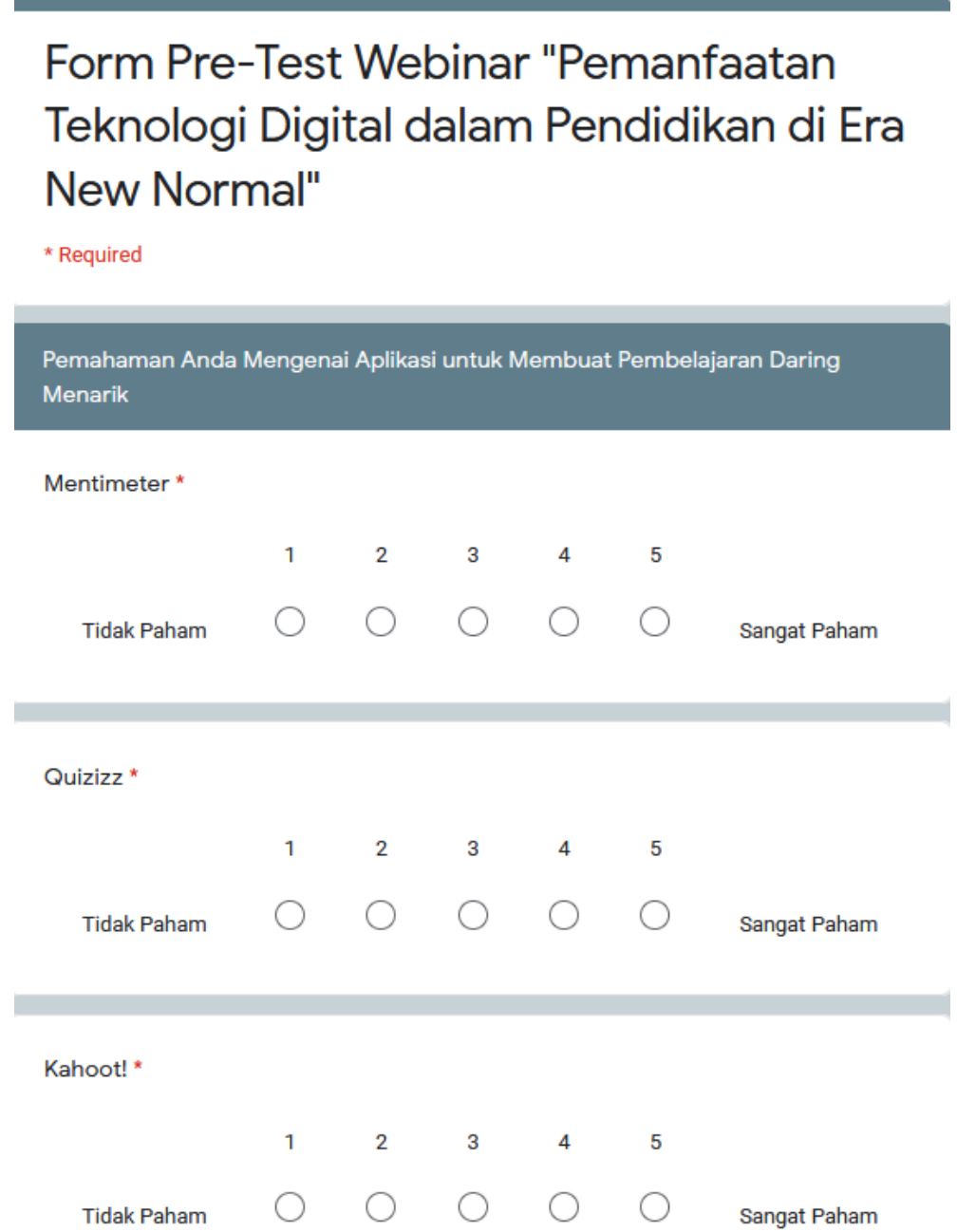

Figure 2. Pre-test form

Participants then get a module that explains the three online learning applications and is explained directly by experts during the webinar. Figure 3 shows the webinar documentation. The explanation given includes a description, purpose, benefits, features, and procedures for operating each application. 


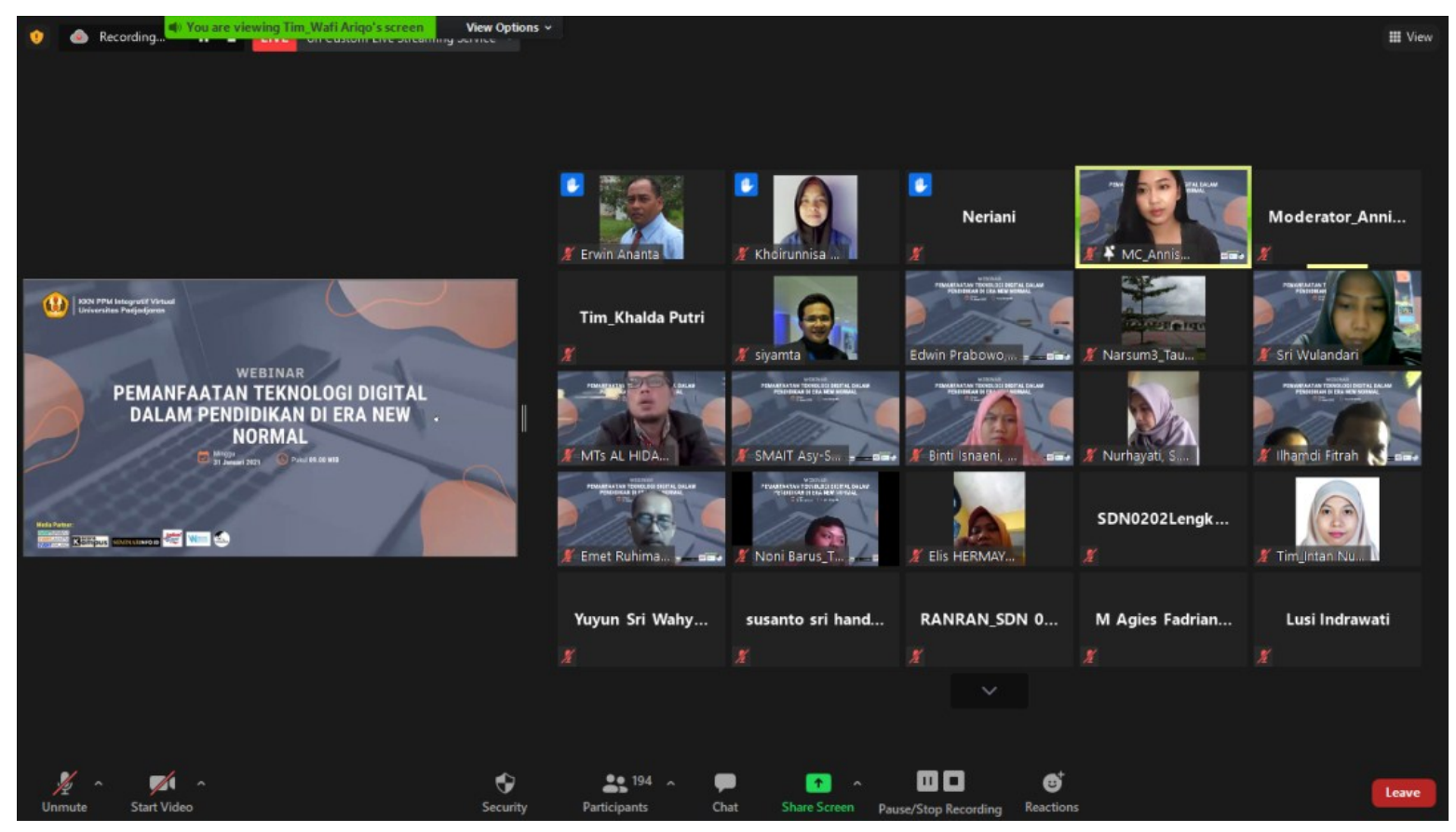

Figure 3. Webinar Documentation via Zoom Meeting
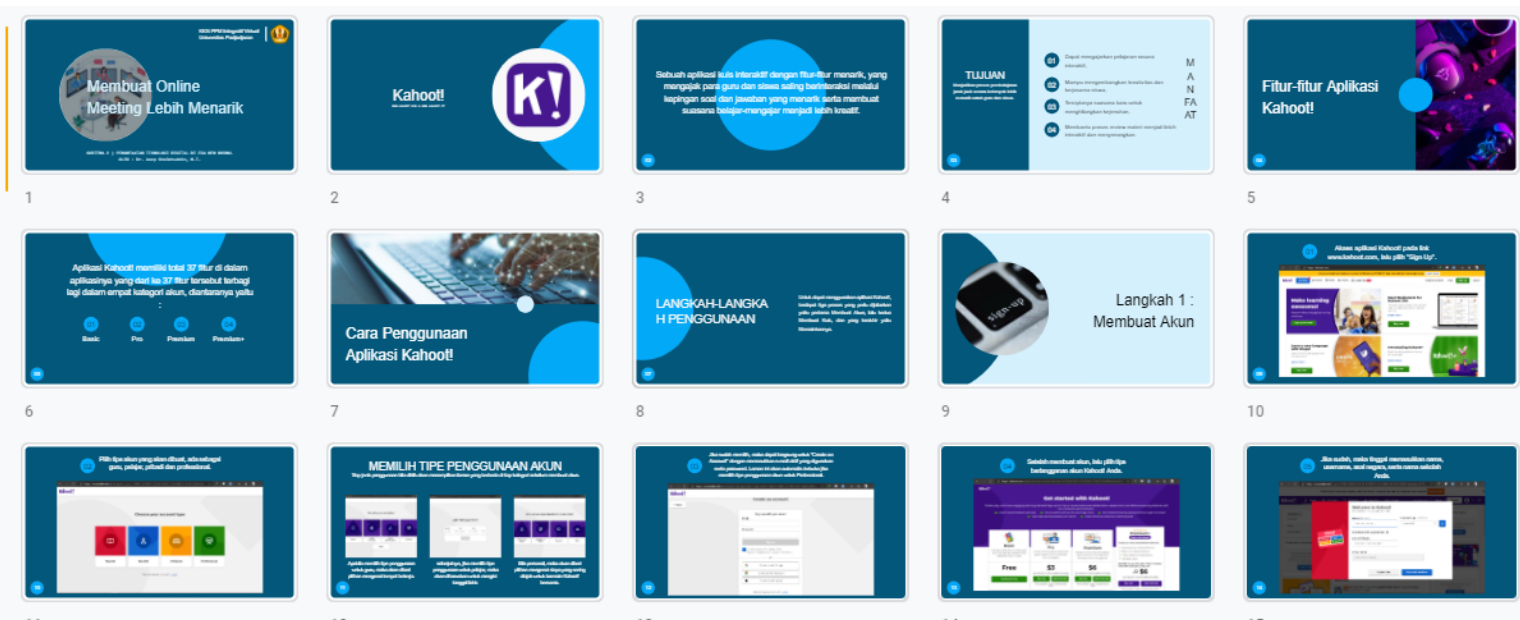

12

Figure 4. An Example of Module Used during Webinar

After getting the material in the webinar that shown in Figure 4, participants are asked to fill out the post-test form to determine participants' understanding after participating in the entire series of webinar events. The assessment given by participants is on a Likert scale of $1-5$, number 1 means that they do not understand very well to 5 which means that the participants are very familiar with the material explained in the webinar. Some questions of post-test are shown in Figure 5. 


\section{Form Post-Test dan Evaluasi Webinar "Pemanfaatan Teknologi Digital dalam Pendidikan di Era New Normal"}

\section{Pemahaman Anda Mengenai Aplikasi untuk Membuat Pembelajaran Daring}

Menjadi Menarik Setelah Mengikuti Webinar

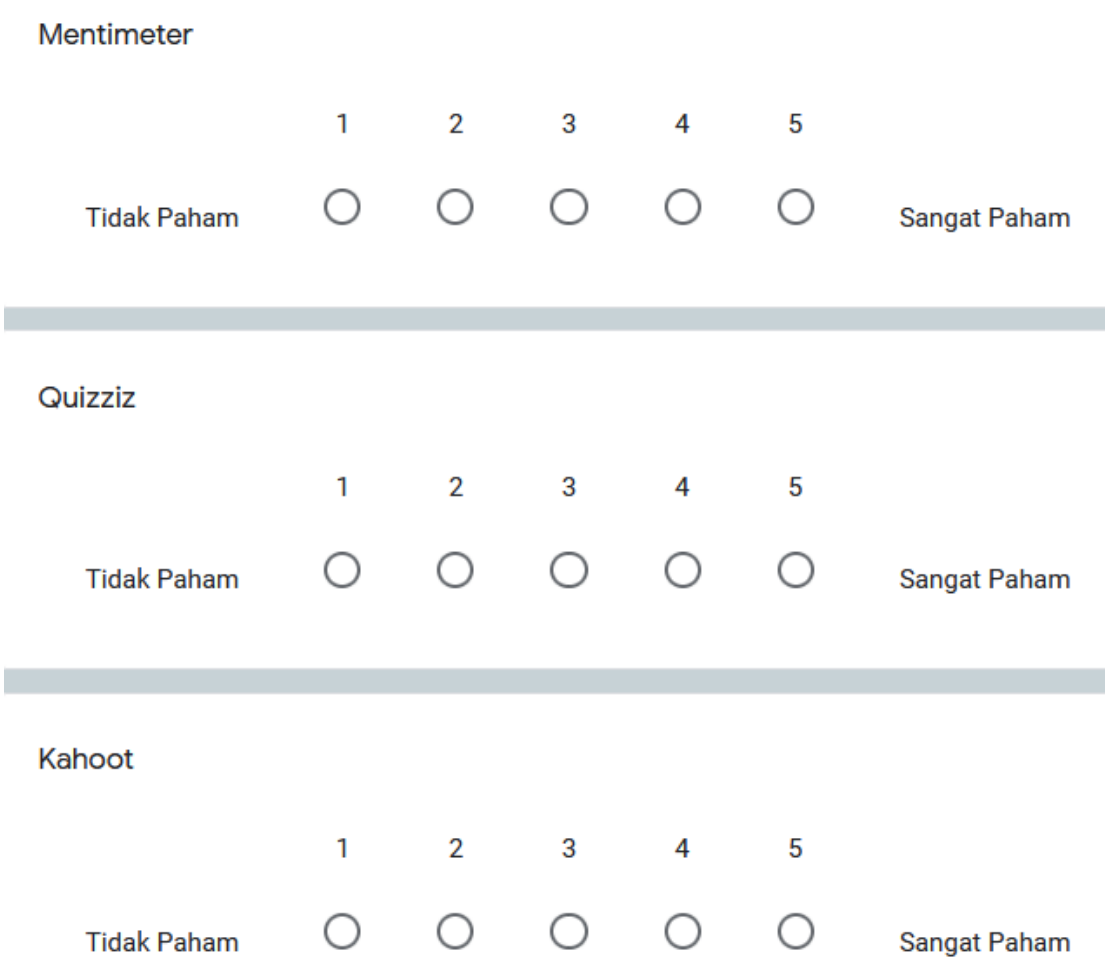

Figure 5. Post-test form

\section{RESULT AND DISCUSSION}

Assessment of participants' understanding of online learning applications through the pretest and post-test forms filled out by 266 participants. The calculation of the total score is done by adding a score of 2.5 for every increase of 1 number from pre-test to post-test and each decrease of 1 number is given a score of -2.5 . For example, each participant experienced an increase in understanding of the meter by 1-2 points between the pre-test and post-test. If calculated as a whole there are 297 increases from 266 participants. Since the condition is increasing, we multiply 297 by 2.5 and we get 742.5 . The average increase is obtained by dividing 742.5 by 266 and then multiplying by 10 to get $28 \%$. 
Table 1. An Overview of Participant's Knowledge on Interesting Online Learning Applications

\begin{tabular}{|c|c|c|c|}
\hline No. & Aplication & $\begin{array}{c}\text { Total } \\
\text { Score }\end{array}$ & $\begin{array}{c}\text { Percentage } \\
\text { Increase }\end{array}$ \\
\hline 1 & Mentimeter & 742.5 & 28 \\
\hline 2 & Kahoot & 625 & 23 \\
\hline 3 & Quizizz & 477.5 & 18 \\
\hline
\end{tabular}

Based on data at Table 1, it can be seen that the three materials presented in the webinar managed to have a good impact on participants' understanding of digital technology that can be used to make online meetings or online classes more interesting. However, these three applications are not applications that get a significant improvement overall from all application materials submitted during the course of the webinar.

Technical constraints may be the cause of the less than optimal increase in teacher knowledge. This study experienced a few technical problems, including internet signal disturbances during the webinar and miscommunication with the webinar host regarding the distribution of participant's post-test links. This obstacle can cause the material given during the webinar may not be delivered in its entirety. The author hopes that future researchers can use this as an evaluation material to develop and make future research or webinar activities even better.

The follow-up form of the webinar that the author did was the provision of webinar material and modules containing more detailed explanations of applications that support online learning to participants. These modules and materials are expected to provide participants with guidelines that contain more in-depth information, making it easier for participants to apply it to the online learning process at school.

\section{CONCLUSIONS}

This webinar aims to provide education about interesting online learning applications as a teacher support tool during online learning. Assessments in the form of pre-test and posttest were conducted to evaluate the teacher's level of understanding before and after the webinar was conducted. Based on the calculations of the two tests, the results showed that there was an increase in participant's understanding of the Mentimeter application by $28 \%$, Kahoot by $23 \%$, and Quizizz by $18 \%$. Based on these calculations, it can be said that participants experienced an increased understanding of applications that support the creation of interesting online learning such as Kahoot, Mentimeter, and Quizizz from this webinar.

\section{ACKNOWLEDGEMENT}

We thanks to Directorate of Research and Community Service, Universitas Padjadjaran for funding this activity. Also, this work is supported by the Research Center of Artificial Intelligence and Big Data, Universitas Padjadjaran. 


\section{LIST OF REFERENCES}

Asmuni, A. (2020). Problematika Pembelajaran Daring di Masa Pandemi Covid-19 dan Solusi Pemecahannya. Jurnal Paedagogy 7(4), 281-288.

Churiyah, M., Sholikhan, S., Filianti, F., \& Sakdiyyah, D. A. (2020). Indonesia education readiness conducting distance learning in Covid-19 pandemic situation. International Journal of Multicultural and Multireligious Understanding 7(6), 491-507.

Dewi, M. P., \& Wajdi, M. B. (2021). Distance learning policy during pandemic COVID-19. EDUTEC: Journal of Education and Technology 4(3), 325-333.

Firman, F., \& Rahayu, S. (2020). Pembelajaran online di tengah pandemi covid-19. Indonesian Journal of Educational Science 2(2), 81-89.

Khasanah, D. R., Pramudibyanto, H., \& Widuroyekti, B. (2020). Pendidikan dalam masa pandemi covid-19. Jurnal Sinestesia 10(1), 41-48.

Magrath, I., Steliarova-Foucher, E., Epelman, S., Ribeiro, R. C., Harif, M., Li, C. K., \& ... Howard, S. C. (2013). Paediatric cancer in low-income and middle-income countries. The lancet oncology 14(3), e104-e116.

Pratama, L. D., Lestari, W., \& Astutik, I. (2020). Efektifitas Penggunaan Media Edutainment Di Tengah Pandemi Covid-19. AKSIOMA: Jurnal Program Studi Pendidikan Matematika 9(2), 413-423.

Purwanto, A., Pramono, R., Asbari, M., Hyun, C. C., Wijayanti, L. M., \& Putri, R. S. (2020). Studi eksploratif dampak pandemi COVID-19 terhadap proses pembelajaran online di sekolah dasar. EduPsyCouns: Journal of Education, Psychology and Counseling 2(1), 1-12.

Saputra, A. (2018). Allocation of Education Budget in Indonesia. Budapest International Research and Critics Institute (BIRCI-Journal): Humanities and Social Sciences 1(2), 141-147.

Thorik, S. H. (2020). Efektivitas pembatasan sosial berskala besar di Indonesia dalam penanggulangan Pandemi Covid-19. $A D A L A H, 4(1)$. 